\title{
Ecological and environmental education in the ethical context
}

\author{
Wychowanie ekologiczne, środowiskowe \\ w kontekście etyki
}

*Dr hab. Ilona Żeber-Dzikowska, prof. nadzw., Institute of Humanities and Social Sciences, The State School of Higher Professional Education in Płock, Gałczyńskiego 28 St., 09-400 Płock; Institute of Biology, the Jan Kochanowski University in Kielce, Swietokrzyska 15 St., 25-406 Kielce, e-mail: ilona.zeber-dzikowska@ujk.edu.pl
${ }^{* *}$ Dr Jarosław Chmielewski, Institute of Environmental Protection-National Research Institute, Krucza 5/11d St., 00-548 Warsaw, e-mail: jaroslaw. chmielewski@ios.edu.pl

*** Drhab. Mariola Wojciechowska, prof. nadzw., The Faculty of Pedagogy and Arts, Institute of Pedagogy and Psychology, the Jan Kochanowski University in Kielce, Krakowska 1 St., 25-029 Kielce; e-mail: mariola.wojciechowska@vp.pl

Keywords: ecological education, environmental education, ecology, environmental protection, ethics, society Słowa kluczowe: wychowanie ekologiczne, wychowanie środowiskowe, ekologia, ochrona środowiska, etyka, społeczeństwo

\section{Abstract}

In the article, the authors elaborate on an important aspect concerning ecological and environmental education in the context of complex ethical issues. They make the reader aware of the crucial role education serves when it is connected with pro-ecological and pro-environmental education as well as ecological ethics, which aims at determining a man's attitude towards nature. They stress the importance of ecological ethics for society to function properly. Ethics is an inherent element of the whole universe, and primarily of ecology and environmental protection, which the article tries to present and prove. Not only does ethics refer to environmental protection, but also becoming familiar with nature. Most people do not realise what danger they can expose one another to until they experience it themselves. A man is not capable of existing without the resources the nature provides us with, which is an adequate reason why we should take care of it the best we can. To achieve it, new regulations to be observed are introduced. They are designed to make us stop progressive environmental degradation and also, restore the environment. People perform an important role in the existence of the environment as long as they treat it rightfully by following the voice of their conscience, which can influence its survival. We should take care of nature, treat it as a family member with love and kindness and then we can be sure it will not surprise us with something unexpected. We should take care of everything nature consists of, that is, plants, animals, water, soil and air because when we take care of all these aspects, we also take care of ourselves and the whole society.

() IOŚ-PIB

\section{INTRODUCTION}

Development of modern civilisation and global ecological crisis has resulted in the situation in which polemics over a man's attitude to nature that surrounds us have become widespread and prevailing. We are becoming more and more convinced that ecological and environmental education is important. It is much easier for us to visualise the world without people than people without the Earth.

\section{Streszczenie}

Autorzy w przygotowanym artykule przedstawili ważny aspekt dotyczący wychowania ekologicznego, środowiskowego w kontekście złożonej problematyki zagadnień etycznych. Uzmysławiają czytelnikowi jak ważną rolę odgrywa edukacja powiązana $z$ wychowaniem proekologicznym, prośrodowiskowym, jak również z etyką ekologiczną, która ma na celu określenie stosunku człowieka do przyrody. Uświadamiają znaczenie etyki ekologicznej w prawidłowym funkcjonowaniu społeczeństwa. Etyka jest nieodłącznym elementem całego wszechświata, a przede wszystkich ekologii i ochrony środowiska, co próbowano przedstawić i udowodnić w artykule. Oprócz ochrony środowiska, etyka dotyczy również zapoznawania z naturą. Większość ludzi nie uświadamia sobie, jakie niebezpieczeństwo mogą sobie nawzajem stworzyć. Człowiek nie jest zdolny do życia bez zasobów, jakie dostarcza nam przyroda, co jest ważnym powodem, dla którego należy jak najlepiej o nią dbać. W tym celu powstają również nowe przepisy, które należy przestrzegać. Zobowiązują nas do powstrzymania postępującej degradacji środowiska a także do jego odnowienia. Ludzie odgrywają ważną rolę $w$ istnieniu środowiska, jeśli postępują wobec niego zgodnie z zasadami zrównoważonego rozwoju, co może wpłynąć na jego przetrwanie. Należy dbać o przyrodę, traktować ją jak członka rodziny z miłością i dobrocią, wtedy będziemy mieć pewność, że nie zaskoczy nas niczym nieoczekiwanym. Powinniśmy dbać o wszystko, co wchodzi w skład przyrody tj. rośliny, zwierzęta, wody, gleby oraz powietrze, ponieważ, jeśli dbamy o te elementy, dbamy również o nas samych oraz całe społeczeństwo.

We are on the threshold of the new era, which, hopefully, will be a century of ecology. The new era needs people thinking differently, holding a different value system, perceiving differently their own place on our planet. Today, we need to provide ecological education. Before we try to bring up a young man and educate him how to live in harmony with nature following demands of correctly comprehended ecology, we must delve into the meaning 
of this word. It is good to begin with the definition of ecology as an area of biology that explores mutual dependence between living organisms and also, between them and surrounding environment. The outcome of research conducted for many years is a complex picture of the world in which all its elements (plants, animals, soil, air) are interlocked in a great variety of ways. When we want to protect our world, we need to protect life in its every form. If we wish to raise children applying principles of widely understood ecology, our didactic process has to include such a perspective of the world.

\section{ECOLOGY - ECOLOGICAL EDUCATION - ENVIRONMENTAL EDUCATION}

The term of ecology in everyday use as well as in various specialised discussions: in the media, marketing or political enjoys continuing popularity nowadays.

In one definition, 'ecology is a man's thorough knowledge of the natural environment, natural phenomena, their mutual dependence and roots; global effects of economic processes and industrial action; influence of daily consumers' activities on the environment; competence and attitudes in favour of environmental protection and respecting nature as well as multifaceted understanding of the quality of life on the Earth' [Sobczyk 2001].

Generally speaking, ecological education, also referred to as environmental education, is the total of activities and pedagogical processes which enable people to comprehend surrounding natural reality and influence their attitudes towards the surrounding world' [Pilch (red.) 2003].

\section{THE CONCEPT AND UNDERSTANDING OF ETHICS IN THE CONTEXT OF ENVIRON- MENTAL ISSUES}

Man is an environmental being. Human development always occurs in a specified natural environment. It can easily be noticed that creatures that surround a man establish some kinds of relation with him. Natural environment is good and should be looked after and protected. Thus, it attracts interest of ethics [Dobrzańska et al. 2008; Hull, Tulibacki (red.) 1996].

The primeval understanding of ethics concerns issues of an adult person as an individual and interpersonal relations both in individual and social scales. A moral man is capable of profound recognition of values and shaping his own freedom. A person is recognised as the central form of being and its most perfect manifestation. He creates regulations and responsibilities since he can choose goods that predispose him to head for the ultimate aim he has set himself. The choice is not decided as it is limited by law, which, in the name of justice, makes him consider, with other people, the way the goods are used. People are equally classified for the united goodness so, by operation of law, a person can demand some action should be either taken or stopped.

It is worthwhile to ponder over the term of ethics and how it should be understood in the context of the issue discussed above. Ethics is characterised by the word 'habit' or 'custom' (from the Greek term ethos) [Woleński, Hartman 2008]. Through 'habit', we can understand a pattern of behaviour that is achieved by some action being performed repeatedly. The term 'custom' refers to behaviour that can be learned by watching and copying others. Ethics can also be understood as knowledge including clues that refer to performing actions which do not have any negative influence on any sphere of life. The fact that ethics exists has been known from way back but, in the course of time, it has been improved and now covers a vast area of significant importance in a man's life. Ethics can be divided into normative and descriptive one. Descriptive ethics is connected with the term 'morals', which lets us understand whether our actions are right or wrong. Not every man is capable of doing the right thing, but we should not judge a person harshly since he may not realise that what he is doing is wrong. Normative ethics is, however, distinct from morals as it includes a set of rules we should apply. [Woleński, Hartman 2008]. It remains necessary to extend the range of ethical value considerations and undertake a moral assessment of various forms of human activity in the natural world.

\section{EDUCATIONAL CAMPAIGN AIMED AT PRESERVING THE ENVIRONMENT}

The depreciation of the natural environment poses a serious danger to a man's functioning. The situation is considered not only in an environmental or technical scale. Research into the phenomenon of ecological crisis indicates that it is tightly linked with moral crisis. Inappropriate human activity towards the natural environment results from philosophical, religious, ethical and economic beliefs. The change in the world of a man's moral values, where material values become more important than personal ones, leads to serious exploitation of the world of nature and ecology. Consequently, major threat to human life is posed. So, the situation calls for undertaking an educational campaign that will result in overcoming the threat and saving the world from ecological disaster in the future. The aim of the educational campaign is to protect nature from another degradation and to contribute to its renewal. Activity in the area of ethics is also emphasised since man as a moral being should be aware and responsible for the surrounding reality.

\section{THE SIGNIFICANCE OF ENVIRONMENTAL PROTECTION}

Environmental protection and the question of its degradation make it difficult for people to understand the significance of consequences of their own activity. Knowledge and values a man applies in his life rather frequently tend not to meet the demands of the reality. Man's ability to destroy natural world is also a problem of much deeper character than it may appear. Global warming, the ozone layer or alarming rate at which animals and plants are becoming extinct have a common origin, that is, man and his civilisation's attitude towards the natural world, which relies on taking and not looking back. Although recently, the need to respect nature has been campaigned for more and more often, in fact, not much follows it.

Environmental protection is the necessity to become aware of a man's frequently destructive influence on natural world and it 
led to the origin of environmental ethics. This branch of ethics refers to questions of moral relations between an individual, various social groups and whole societies and human habitat. Dramatic threats to the natural environment make philosophers conclude that ethics cannot only be limited to the world of human relations as it overlooks a large area of human relations with the surrounding natural world.

\section{ECOLOGICAL AWARENESS - ECOLO- GICAL KNOWLEDGE - AIMS OF ECOLO- GICAL EDUCATION}

Ecological awareness is primarily: knowledge of dependence between parts of nature and between society and nature, a system of values, rules and activity norms as well as sensitivity understood as ability to predict ecological consequences of undertaken actions. Ecological education aims at providing an individual with ecological knowledge (a specified set of information combined in cause and effect system concerning functioning of the natural environment and dependence between it and the civilisation), providing a set of values and their normative equivalents as well as shaping an ecological attitude understood as a developed sense of link with nature and its parts, readiness to defend and protect it, which manifests itself in specified actions.

According to Ligia Tuszyńska [2006], ecological education makes it possible to achieve the following targets:

- 'discovering relations between particular groups of phenomena and organisms,

- training to observe phenomena that occur in the environment and individual organisms,

- describing and comparing the observed phenomena,

- searching for causes of occurrence of some natural phenomena and environmental changes,

- generating motivation for acquiring knowledge about nature and condition of the environment,

- shaping sense of responsibility for condition of the surrounding nature,

- $\quad$ readiness for active participation in activities that lead to improving condition of the environment,

- willingness to become familiar and study phenomena occurring in the natural world and environment, forming opinions and beliefs, shaping lasting and positive attitude towards the environment.'

\section{ENVIRONMENTAL ETHICS IN THE PROCESS OF ECOLOGICAL EDUCATION}

The role of environmental ethics in the process of ecological education is to provide, suitable for process of the education, set of values and norms that appropriately shape motivations, attitudes and behaviours. In the context of influence of environmental ethics, ecological education works on three levels of education and upbringing:

a. in cognitive approach, it presents and circumstantiates value of the ethics and its normative equivalents,

b. emotional-volitional approach draws attention to shaping and inspiring moral sensitivity to environmental problems, c. behavioural point of view means influencing attitudes and behaviours, which encourages active opposition to activities and processes harmful to the environment.

The place of environmental ethics in ecological education lays the foundation for a discussion on ethical protection of the natural environment of importance comparable to technological, economic or legal protection. The difference between them lies in technological, economic and legal protection being an external form of protecting the natural environment against a man, whereas ethical protection bears the internal character when referring to a human being. The first case shows that the protection is to follow specified technological criteria, calculating profits including ecological losses, respect norms and legal regulations. The other case focusses on human awareness and will. Technological protection bases on sanctions, subordinates a man, imposes constraints on him and exerts pressure. Ethical protection is the expression of intelligence and human freedom, subordinates a man to his set of values, his own sensitivity, personal sensitivity to the good and harm done to the environment.

Recently, people all over the world have been gradually realising the importance of solving environmental problems as well as understanding and predicting them. Their origin lies in social, economic and cultural factors. Environmental problems cannot be solved by means of technology only. It is advisable to influence primarily sets of values, attitudes and behaviours of individuals and communities towards the environment.

\section{MULTIFACETED POSITION OF ECOLO- GICAL ETHICS}

Ecological ethics develops on the basis of traditional ethical systems. Moral concern about the environment results from bilateral influence and needs to realise human ethical principles.

\subsection{Traditional approach}

The current emphasises a man's close relation with the environment. Correlation between the environment and a moral, ethical aspect, which results from awareness that nature influences human needs and interest is advisable to put people's general ethical principles into practice.

\subsection{Respecting animal rights}

Animal rights advocates claim that the range of responsibility people bear towards animals results from the fact that these organisms possess consciousness. In his conduct, a man should not cause suffering, but respect the will to live.

\subsection{Biocentrism}

The approach assumes that universal morality comprising all living creatures exists. It can be divided into two trends: biotic equality and indirect trend. The former assumes that creatures are morally equal. It is deep ecology that rejects anthropocentrism. According to the theory, parts of biosphere are given equal right 
to live, develop and realise own, individual forms of development and self-realisation. We should follow the principle that everything that serves diversity of biosphere is moral.

Advocates of indirect ethics relate principles of protecting any life to acknowledgement of people's exceptional privileges. The reason for a man's activities towards biosphere is evolution, which results in the following suggestions:

- act the way that protects and enhances development of evolution and its diversity,

- act the way that protects and enhances life, which is a crucial condition for development of evolution,

- act the way that preserves and strengthens ecosystems, which are the basis of life and consciousness,

- act the way that protects and enhances abilities, which are the highest forms of evolution of the universe: consciousness, ability to create and sympathise,

- act the way that protects and enhances human life.

\subsection{Ethical intuitionism}

The trend assumes that a man in his conduct towards nature should rely on intuition and conscience. These are meant to govern his conduct [Ciaciura 2007; 2013].

\section{CONCLUSIONS}

Multilayer and cross-curricular education is important for ecological education, which is connected with spreading interdisciplinary knowledge. It is advisable for such education to draw attention to applying natural didactic resources and the possibility to apply such teaching systems that will give a chance to combine theoretical knowledge with practical one. It is important that the knowledge should be shared not only as a piece of news, which will only allow to understand in part how the natural world functions. Such education should primarily shape attitudes responsible for condition of the natural environment and life on the Earth. Also, such education develops perception of the world as a system of interdependent living organisms that harmoniously influence one another. For that reason, the following methods used in ecological education are of considerable importance: field trips, direct observations, contact with nature.

Life is a relationship, so the fundamental value of ecological thinking is respect for life. Destroying any form of life is evil as it weakens the unity comprising all creatures including people. Another ecological value is responsibility. It should cover us, other

\section{REFERENCES}

CIACIURA M. 2007. Etyka ekologiczna. Biuletyn Studentów Instytutu Filozofii US, nr 11.

http://www.us.szc.pl/main.php/archiwumesse/?xml=load_page\& $\mathrm{st}=11689 \& \mathrm{ar}=1 \& \mathrm{id}=6018 \& \mathrm{gs}=\& \mathrm{pid}=14070$ Online accessible: 1 grudnia $2013 \mathrm{r}$.

DOBRZAŃSKA B., DOBRZAŃSKI G., KIEŁCZEWSKI D. 2008. Ochrona środowiska przyrodniczego. PWN. Warszawa.

HULL Z., TULIBACKI W. (red.) 1996. Człowiek wobec świata. Pol. Tow. Filozoficzne i ART. Olsztyn. people, animals, plants, the environment. When a child plants a tree or when his parents realise his dream and buy him a dog or a cat, he should be aware of the responsibility that he bears and decide on it when he is certain he will manage. We cannot ignore another value, which is moderation. We live on the planet, which has limited natural resources. We should benefit from them, but only to satisfy our basic necessities of life. There is a lot to be done in this aspect. We exist in a society governed by material values as well as instrumental and consumerist attitudes.

On the basis of the above consideration, we can conclude that environmental ethics and ecological education are two branches of science that are closely linked. Ethics emphasises that a man must be caring and friendly towards the environment, whereas ecological education indicates specified ways in which a man must take care of the surrounding environment. The main aims of environmental education are: informing about basic environmental problems, drawing attention to cause and effect of all environmental processes, implementing the ability to think and understand interdisciplinarily, teaching the base of ecologically balanced use of the environment and its protection, teaching how to use natural resources economically, shaping ethics that forbids activities against the environment and man, shaping habits of ecological culture, injecting the need to conform to ecological norms and bans and also creating a need and ability to cooperate on environmental protection. The ultimate aim of ecological education and environmental ethics altogether is to inspire a man to love the nature.

Each of us benefits from the natural environment using not only its resources or energy, but also gaining inspiration and experience that come from beauty and majesty of nature. We also benefit from goods of social and cultural environment created by people and for people. Still, not many people understand the influence on the condition and quality of these environments exerted by individuals, families, communities and their actions, habits, lifestyles, fashions, leisure time and eating habits. So, ecological education, which encourages understanding of the relation between a man, his products and the environment, must comprise all people with no exception, beginning with the youngest, who can effectively pass patterns of pro-ecological behaviour to older generations. It is the joint effort of all people together and individually made every day everywhere: at home, work, in their leisure time which can stop environmental degradation, lead to improvement of the quality of our lives and health and ensure perspectives of decent life for future generations.

PILCH T. (red.) 2003. Encyklopedia pedagogiczna XXI wieku, Wydawnictwo Akademickie Żak, Warszawa.

SOBCZYK W. 2001. Edukacja ekologiczna i prozdrowotna. Wydawnictwo Naukowe Akademii Pedagogicznej. Kraków.

TUSZYŃSKA L. 2006. Edukacja ekologiczna dla nauczycieli i studentów, Wyższa Szkoła Pedagogiczna TWP w Warszawie. Warszawa.

WOLEŃSKI J., HARTMAN J. 2008. Wiedza o etyce. Park Edukacja. Torun. 